\title{
The effect of kisspeptin on the regulation of vascular tone ${ }^{1}$
}

\author{
Zsófia Mezei, Omid Zamani-Forooshani, Krisztina Csabafi, Bence Szikszai, Eszter Papp, Ádám Ónodi, \\ Dóra Török, Ádám Leprán, Gyula Telegdy, and Gyula Szabó
}

\begin{abstract}
Kisspeptin has been implicated in cardiovascular control. Eicosanoids play a crucial role in the activation of platelets and the regulation of vascular tone. In the present study, we investigated the effect of kisspeptins on eicosanoid synthesis in platelets and aorta in vitro. Platelets and aorta were isolated from Wistar-Kyoto rats. After preincubation with different doses of kisspeptin, samples were incubated with $\left[1^{-14} \mathrm{C}\right]$ arachidonic acid $(0.172 \mathrm{pmol} / \mathrm{mL})$ in tissue culture Medium 199 . The amount of labeled eicosanoids was measured with liquid scintillation, after separation with overpressure thin-layer chromatography. Kisspeptin-13 stimulated the thromboxane synthesis. The dose-response curve was bell-shaped and the most effective concentration was $2.5 \times 10^{-8} \mathrm{~mol} / \mathrm{L}$, inducing a $27 \%$ increase. Lipoxygenase products of platelets displayed a dose-dependent elevation up to the dose of $5 \times 10^{-8} \mathrm{~mol} / \mathrm{L}$. In the aorta, kisspeptin-13 induced a marked elevation in the production of 6-keto-prostaglandin $\mathrm{F}_{1 \alpha}$, the stable metabolite of prostacyclin, and lipoxygenase products. Different effects of kisspeptin on cyclooxygenase and lipoxygenase products indicate that beyond intracellular $\mathrm{Ca}^{2+}$ mobilization, other signaling pathways might also contribute to its actions. Our data suggest that kisspeptin, through the alteration of eicosanoid synthesis in platelets and aorta, may play a physiologic and (or) pathologic role in the regulation of vascular tone.
\end{abstract}

Key words: kisspeptin, platelets, aorta, eicosanoids.

Résumé : On sait que la kisspeptine agit sur le contrôle des fonctions cardiovasculaires et que les eicosanoïdes jouent un rôle crucial dans l'activation des plaquettes et la régulation du tonus vasculaire. Dans le cadre de la présente étude, nous avons étudié in vitro les effets des kisspeptines sur la synthèse des eicosanoïdes dans les plaquettes et dans l'aorte. Les plaquettes et les aortes de rats Wistar-Kyoto étaient isolées et, après incubation en présence de différentes doses de kisspeptine, les échantillons étaient incubés en présence d'acide $\left[1^{-14} \mathrm{C}\right]$ arachidonique $(0,172 \mathrm{pmol} / \mathrm{mL})$ dans un milieu de culture M199. Après séparation par chromatographie sur couche mince sous pression, nous avons mesuré par scintillation liquide la quantité d'eicosanoïdes marqués. La kisspeptine-13 a permis de stimuler la synthèse de thromboxane : la courbe dose-réponse, en forme de cloche, indiquait que la concentration la plus efficace était de $2,5 \times 10^{-8} \mathrm{~mol} / \mathrm{L}$ pour l'induction d'une augmentation de $27 \%$. Les produits de la lipoxygénase plaquettaire ont augmenté de manière proportionnelle à la dose jusqu'à $5 \times 10^{-8} \mathrm{~mol} / \mathrm{L}$. Dans l'aorte, la

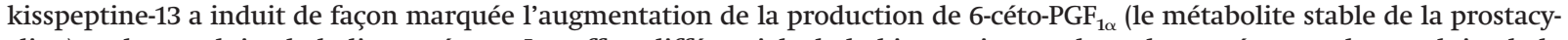
cline) et des produits de la lipoxygénase. Les effets différentiels de la kisspeptine sur la cyclo-oxygénase et les produits de la lipoxygénase laissent penser qu'en plus de la mobilisation du $\mathrm{Ca}^{2+}$ intracellulaire, d'autres voies de signalisation pourraient aussi contribuer à son action. Nos données laissent entendre que la kisspeptine pourrait jouer un rôle physiologique et (ou) pathologique dans la régulation du tonus vasculaire en altérant la synthèse des eicosanoïdes dans les plaquettes et dans l'aorte. [Traduit par la Rédaction]

Mots-clés : kisspeptine, plaquettes, aorte, eicosanoïdes.

\section{Introduction}

Approximately 30 years ago, the tetrapeptide FMRFamide was isolated from the ganglia of clam as a cardioexcitatory peptide (Price and Greenberg 1977). Since then, a number of RF-amide peptides have been identified that all share the Arg-Phe motif at the C-terminal. They possess a wide range of effects that include regulation of vascular tone and cardiac function (Fukusumi et al. 2006).

$\mathrm{KP}$, a member of the RF-amide family, is the product of the Kiss1 gene (Tena-Sempere 2013). The prepropeptide, consisting of 145 amino acids, is cleaved to produce a C-terminally aminated 54 amino acid peptide, KP-54. As a result of alternative splicing, other biologically active derivatives are produced, e.g., KP-14, KP-13, and KP-10 (Tena-Sempere 2013). KPs are one of the main regulators of the reproductive axis; however, by binding to their cognate receptor, GPR54, and by activating the Gq/11, the ERK1/2, and the p38 MAP kinase signaling pathways (Castaño et al. 2009), they might play a role in several other processes.

Furthermore, KPs bind to NPFF receptors (Lyubimov et al. 2010; Elhabazi et al. 2013), the ligand of which (NPFF) has already been

Received 9 January 2015. Accepted 17 April 2015.

Abbreviations: AA, arachidonic acid; COX, total amount of cyclooxygenase metabolites (6-kPGF $1 \alpha, \mathrm{PGF}_{2 \alpha}, \mathrm{TxB}_{2}$, PGE $\mathrm{PGD}_{2}$, and 12-HHT); EDTA, ethylenediaminetetraacetic acid; ERK1/2, extracellular signal-regulated protein kinases 1 and 2; FMRFamide, Phe-Met-Arg-Phe-amide; HETE, hydroxyeicosatetraenoic acid; 12-HETE, 12-hydroxyeicosatetraenoic acid; 12-HHT, 12---hydroxy-5,8,10-heptadecatrienoic acid; KP, kisspeptin; LOX, lipoxygenase; MAP kinase, mitogenactivated protein kinase; NPFF, neuropeptide FF; OPTLC, overpressure thin-layer chromatograph; $\mathrm{PGD}_{2}$, prostaglandin $\mathrm{D}_{2}$; $\mathrm{PGE}_{2}$, prostaglandin $\mathrm{E}_{2}$; 6-kPGF $\mathrm{k}_{1 \alpha}$, 6-keto-prostaglandin $\mathrm{F}_{1 \alpha} ; \mathrm{PGF}_{2 \alpha}$, prostaglandin $\mathrm{F}_{2 \alpha} ; \mathrm{PGI}_{2}$, prostacyclin; $\mathrm{PRP}$, platelet-rich plasma; RFamide peptide, Arg-Phe-amide peptide; TxA $\mathrm{A}_{2}$, thromboxane $\mathrm{A}_{2}$; $\mathrm{TxB}_{2}$, thromboxane $\mathrm{B}_{2}$.

Z. Mezei, O. Zamani-Forooshani, K. Csabafi, B. Szikszai, E. Papp, Á. Ónodi, D. Török, Á. Leprán, G. Telegdy, and G. Szabó. Department of Pathophysiology, University of Szeged, P.O. Box 427, H-6701, Semmelweis u. 1, 6725 Szeged, Hungary.

Corresponding author: Zsófia Mezei (e-mail: mezeizsofia@gmail.com).

1This article is part of a Special Issue entitled "Cardioprotection and Arrhythmias, Part 2." 


\section{Pagination not final (cite DOI) / Pagination provisoire (citer le DOI)}

Can. J. Physiol. Pharmacol. Vol. 93, 2015

reported to cause hypertension and tachycardia, both of which seem to be due to the interaction of peripheral NPFF receptors and adrenergic receptors (Allard et al. 1995). This suggests that KP might have an effect on the cardiovascular system. The expression and possible function of KP has been investigated in the cardiovascular center in the brain, in the heart, and in various vessel types (Maguire et al. 2011). Evidence showed the presence of the KP system in atherosclerosis-prone vessels (Mead et al. 2007) and in edema formation (Sawyer et al. 2011), the latter of which was antagonized by COX inhibition. A recent publication reported that KP has anticoagulant activity, which might be mediated through changes in Ca signaling, consequently leading to a decreased thrombin concentration and platelet number (Qureshi and Kanwal 2011).

Platelets serve as an important link among inflammation, thrombosis, and atherogenesis. The active products of the intact endothelium (e.g., prostacyclin and nitric oxide) can inhibit platelet and leukocyte adhesion to the vascular surface and maintain a balance between prothrombotic and antithrombotic activity (Hadi and Suwaidi 2007). Inflammation is amplified by the interactions among platelets, leukocytes, and endothelial cells. These interplays can trigger autocrine and paracrine activation that lead to leukocyte recruitment into the vascular wall. Consequently, a platelet-induced chronic inflammatory process at the vascular wall results in the development of atherosclerotic lesions and atherothrombosis (Gawaz et al. 2005). One of the most important regulators of these processes are lipid mediators. The octadecanoids, eicosanoids, and docosanoids, synthesized from the appropriate polyunsaturated fatty acids, play an important role in the regulation of cell (e.g., platelets, leukocytes, endothelial cells, vascular smooth muscle cells) functions under physiologic or pathologic conditions. The eicosanoids are the metabolites of AA released from the membrane phospholipids by phospholipase $\mathrm{A}_{2}$. Three classes of enzymes are responsible for metabolizing AA: COXs, LOXs, and cytochrome P450 monooxygenases. Activation of the COX pathway leads to the formation of prostaglandins and prostacyclin, the LOX pathway produces the HETEs, and the cytochrome P450 monooxygenase pathway synthesizes the epoxyeicosatrienoic acids. Several cell types engage in AA metabolism, through which different classes of eicosanoids are assembled consequently targeting a variety of cells (Eritsland 2000; Bogatcheva et al. 2005; Russo 2009; Raphael and Sordillo 2013), and thus eicosanoids play a crucial role in platelet activation and regulation of vascular tone (Sellers and Stallone 2008; Félétou et al. 2010). The effects of KP on vasculature and platelets have already been investigated (Mead et al. 2007; Maguire et al. 2011; Qureshi and Kanwal 2011).

On the basis of previous findings in the literature, it may be hypothesized that eicosanoids mediate the effects of KP on the vasculature and platelets. Therefore, in the present study, we aimed to investigate the effect of KP-13, a biologically active form of KP that binds to both GPR54 and NPFF receptors (Elhabazi et al. 2013), on eicosanoid synthesis in platelets and aorta under resting condition in vitro.

\section{Methods}

\section{Chemicals}

$\left.{ }^{14} \mathrm{C}\right] \mathrm{AA}$ (specific activity: $2035 \mathrm{MBq} / \mathrm{mmol}$ ) was from Amersham (England). Serum-free tissue culture Medium 199 was purchased from Sigma (St. Louis, Missouri, USA). Silica gel thin-layer plates $(0.25 \mathrm{~mm})$ were obtained from Merck AG (Darmstadt, Germany). AA (grade 1), 12-HHT, and 12-HETE, used as unlabeled standards, were purchased from Sigma (St. Louis, Missouri, USA). KP-13 was purchased from Bachem (Bubendorf, Switzerland). $\mathrm{PGE}_{2}, \mathrm{PGD}_{2}$, $\mathrm{TxB}_{2}, \mathrm{PGF}_{2 \alpha}$, and 6-kPGF $1 \alpha$ were generously provided by Upjohn Co. (Kalamazoo, Michigan, USA).

\section{Animals}

Adult male Wistar-Kyoto rats, weighing 210-230 g $(n=6)$, were used. The animals were maintained on $12 \mathrm{~h}$ dark : $12 \mathrm{~h}$ light cycles in a room at constant temperature $\left(23 \pm 1^{\circ} \mathrm{C}\right)$ with access to standard laboratory food and water ad libitum. Animal experiments were performed under a protocol accepted by the Ethical Committee for the Protection of Animals in Research at the University of Szeged, Hungary. All experiments were carried out in accordance with the Guide for the Care and Use of Laboratory Animals published by the US National Institutes of Health.

\section{Isolation of platelets}

Under ether anesthesia, blood was drawn from the abdominal aorta of rats and diluted (1:2) with phosphate buffer ( $\mathrm{pH} 7.4)$ containing EDTA $(5.8 \mathrm{mmol} / \mathrm{L})$ and glucose $(5.55 \mathrm{mmol} / \mathrm{L})$. PRP was collected after the whole blood had been centrifuged at $200 \mathrm{~g}$ for $10 \mathrm{~min}$ at room temperature. Platelets were separated from the supernatant by centrifugation at $2000 \mathrm{~g}$ for $10 \mathrm{~min}$, and the pellet was used for further separation. Since the contaminating red blood cells could metabolize AA via the LOX pathway and release leukotrienes (Kobayashi and Levine 1983), the erythrocytes were lysed with hyposmic ammonium chloride $(0.83 \%, 9$ parts) containing EDTA $\left(0.02 \%, 1\right.$ part) at $4{ }^{\circ} \mathrm{C}$ for $15 \mathrm{~min}$. The platelets were then washed with phosphate buffer $(\mathrm{pH} \mathrm{7.4}$, containing $5.8 \mathrm{mmol} / \mathrm{L}$ EDTA and $5.55 \mathrm{mmol} / \mathrm{L}$ glucose) and centrifuged at $2000 \mathrm{~g}$ for $10 \mathrm{~min}$ at room temperature. During the separation procedure, platelet activation was inhibited by using a $\mathrm{Ca}^{2+}$-free medium and siliconized glassware. The washed platelet suspension was free from other cellular elements of the blood (red blood cells, leukocytes, etc.) and plasma proteins. After the last centrifugation, platelets were resuspended $\left(2 \times 10^{8}\right.$ platelets $\left./ \mathrm{mL}\right)$ in serum-free Medium 199 tissue culture.

\section{Isolation of the abdominal aorta}

Under ether anesthesia, after taking blood from rats, the abdominal aorta was isolated. The fat and connective tissue was removed from the aorta, which was then sliced into $1-2 \mathrm{~mm}$ rings with care to not damage the endothelium.

\section{Analysis of eicosanoids}

Platelets $\left(2 \times 10^{8}\right.$ cells $/ \mathrm{mL}$ in each sample) were preincubated in the presence of different concentrations of KP-13 $\left(0,1 \times 10^{-8}, 2.5 \times\right.$ $10^{-8}, 5 \times 10^{-8}, 7.5 \times 10^{-8}$, and $\left.1 \times 10^{-7} \mathrm{~mol} / \mathrm{L}\right)$ at $37^{\circ} \mathrm{C}$ for $5 \mathrm{~min}$, while the aorta rings (15 $\mathrm{mg}$ wet mass $/ \mathrm{mL}$ in each sample) were preincubated for $10 \mathrm{~min}$ in tissue culture Medium 199. The applied concentrations of KP were based on previous in vitro studies investigating KP's effect on different cell lines (Kotani et al. 2001; Taylor et al. 2014).

The enzyme reaction was started by pipetting the tracer substrate $\left[{ }^{14} \mathrm{C}\right] \mathrm{AA}(3.7 \mathrm{kBq}, 0.172 \mathrm{pmol} / \mathrm{mL}$ in each sample) into the incubation mixture. Ten minutes later in platelets, and $30 \mathrm{~min}$ later in aorta samples, the enzyme reaction was stopped by bringing the $\mathrm{pH}$ to 3 with formic acid. The samples were then extracted twice with $3 \mu \mathrm{L}$ of ethyl acetate and the organic phases were pooled and evaporated to dryness under nitrogen. The residues were reconstituted twice in $100 \mathrm{~mL}$ of ethyl acetate and quantitatively applied to silica gel $\mathrm{G}$ thin-layer plates. The plates were developed to a distance of $16 \mathrm{~cm}$ in the organic phase of ethyl acetate - acetic acid - 2,2,4-trimethylpentane - water (110:20:30: 100) by means of OPTLC (Chrompres 25, Labor MIM, Hungary) (Abdel-Halim et al. 1980; Cryer 2009). Each $3 \mathrm{~mm}$ band of the chromatograms was then scraped off and the radioactivity was determined with a liquid scintillation analyzer (TRI-CARB 2100TR, Canberra Packard, USA), using $5 \mathrm{~mL}$ of toluene containing $0.44 \%(\mathrm{~m} / \mathrm{v})$ 2,5-diphenyloxazole, $0.02 \%(\mathrm{~m} / \mathrm{v})$ 1,4-di-[2-(5-phenyl)oxazoyl]benzene, and $10 \%(v / v)$ ethanol. Radioactivity was expressed in disintegrations per minute (dpm). The radio-labeled products of AA were identified with unlabeled authentic standards (Kiefer et al. 1975), i.e., 6- $\mathrm{KPGF}_{1 \alpha}$ 
Fig. 1. The effect of kisspeptin-13 (KP) on the synthesis of platelet cyclooxygenase and lipoxygenase metabolites. Data are the means \pm SE of 6 samples/animals, in disintegrations per minute $(\mathrm{dpm}) .{ }^{*}$, indicates a statistically significant difference compared with the untreated, control samples at $P<0.05$.

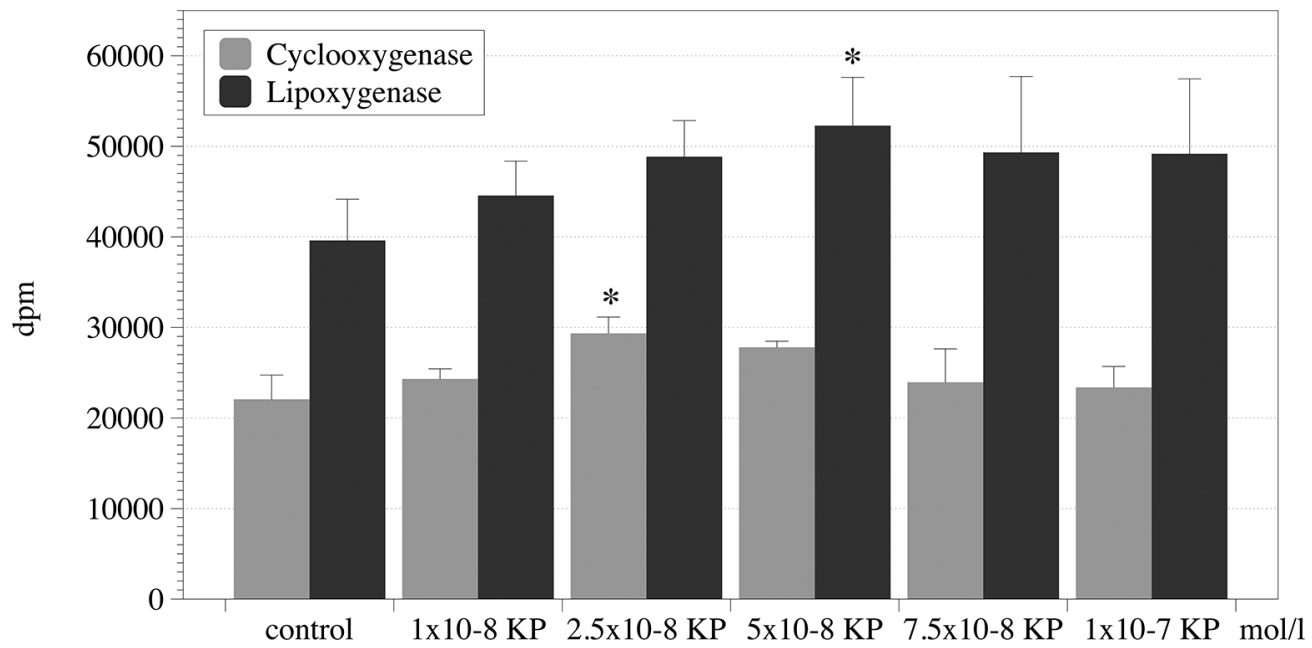

Fig. 2. The effect of kisspeptin-13 (KP) on the synthesis of platelet thromboxane $B_{2}$. Data are the means \pm SE of 6 samples/animals, in disintegrations per minute $(\mathrm{dpm})$. *, indicates a statistically significant difference compared with the untreated, control samples at $P<0.05$.

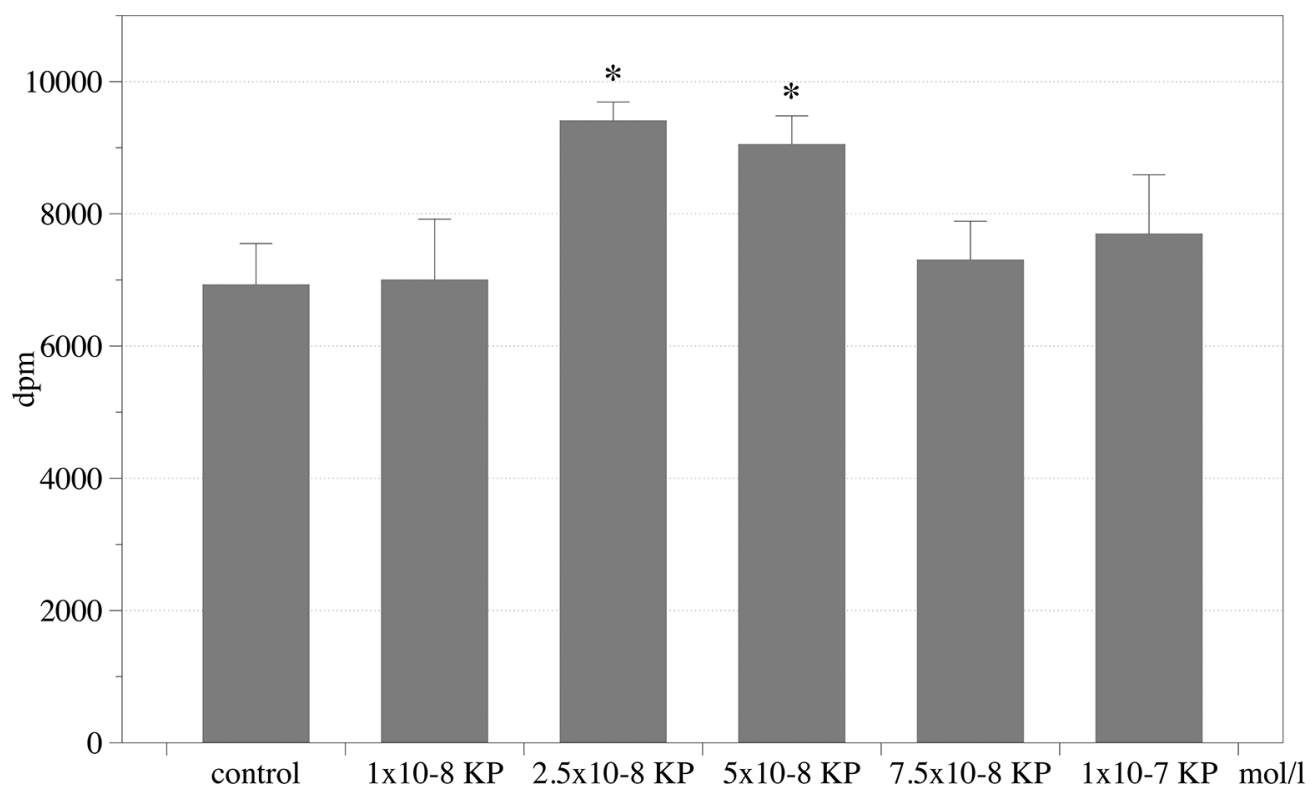

$(\mathrm{Rf}=0.21)$ and HETEs in one peak $(\mathrm{Rf}=0.71)$, which were detected with anisaldehyde reagent (Mezei et al. 2000). Assuming that the exogenously administered $\left[{ }^{14} \mathrm{C}\right] \mathrm{AA}$, as a tracer, is converted in the same way as the endogenous source, our method allows measurement of the relative amounts of various prostanoids.

\section{Statistical analysis}

The results are expressed as means \pm SE. The significance of the differences between the eicosanoid syntheses of the KP-treated and the control platelets were evaluated by one way analysis of variance (ANOVA), followed by Tukey's multiple comparison post hoc test. A difference at a $P$ level of $<0.05$ was considered statistically significant. The statistical analysis was performed by SigmaPlot version 11 (Systat Software, California, USA).

\section{Results}

The total amount of COX metabolites $\left(6-\mathrm{kPGF}_{1 \alpha}, \mathrm{PGF}_{2 \alpha}, \mathrm{TxB}_{2}\right.$, $\mathrm{PGE}_{2}, \mathrm{PGD}_{2}$, and 12-HHT) synthesized by rat platelets was signifi- cantly elevated by $2.5 \times 10^{-8} \mathrm{~mol} / \mathrm{L} \mathrm{KP}-13$, from $22068 \pm 2669$ to $29343 \pm 1800 \mathrm{dpm}$. The investigation of the effects of the different doses of KP-13 on the COX metabolites production showed a bell-shaped form (Fig. 1).

In our experiments, the synthesis of $\mathrm{TxB}_{2}$ in platelets was stimulated by KP-13. The dose-response curve showed a bell-shaped correlation, and the most effective KP-13 concentration was $2.5 \times$ $10^{-8} \mathrm{~mol} / \mathrm{L}$, inducing an increase in production of $\mathrm{TxB}_{2}$ from $6934 \pm 617$ to $9415 \pm 276 \mathrm{dpm}$ (Fig. 2). No significant changes were detected for the other COX metabolites.

LOX products of platelets also showed a dose-dependent elevation (from $39605 \pm 4553$ to $52284 \pm 5331 \mathrm{dpm}$ ) up to a dose of $5 \times$ $10^{-8} \mathrm{~mol} / \mathrm{L} \mathrm{KP}$, beyond which further stimulation was not possible (Fig. 1).

In the aorta, the production of $6-\mathrm{kPGF}_{1 \alpha}$ was increased significantly when $5 \times 10^{-8} \mathrm{~mol} / \mathrm{L} \mathrm{KP-13}$ was applied (Fig. 3). The total amount of COX metabolites $\left(6-\mathrm{kPGF}_{1 \alpha}, \mathrm{PGF}_{2 \alpha}, \mathrm{TxB}_{2}, \mathrm{PGE}_{2}, \mathrm{PGD}_{2}\right.$, and 12-HHT) synthesized by rat aorta showed only a slight eleva- 


\section{Pagination not final (cite DOI) / Pagination provisoire (citer le DOI)}

Fig. 3. The effect of kisspeptin-13 (KP) on the synthesis of 6-keto-prostaglandin $\mathrm{F}_{1 \alpha}\left(6-\mathrm{kPGF}_{1 \alpha}\right)$ and lipoxygenase metabolites in aorta. Data are the means \pm SE of 6 samples/animals, in disintegrations per minute (dpm). ${ }^{*}$, indicates a statistically significant difference compared with the untreated, control samples at $P<0.05$.

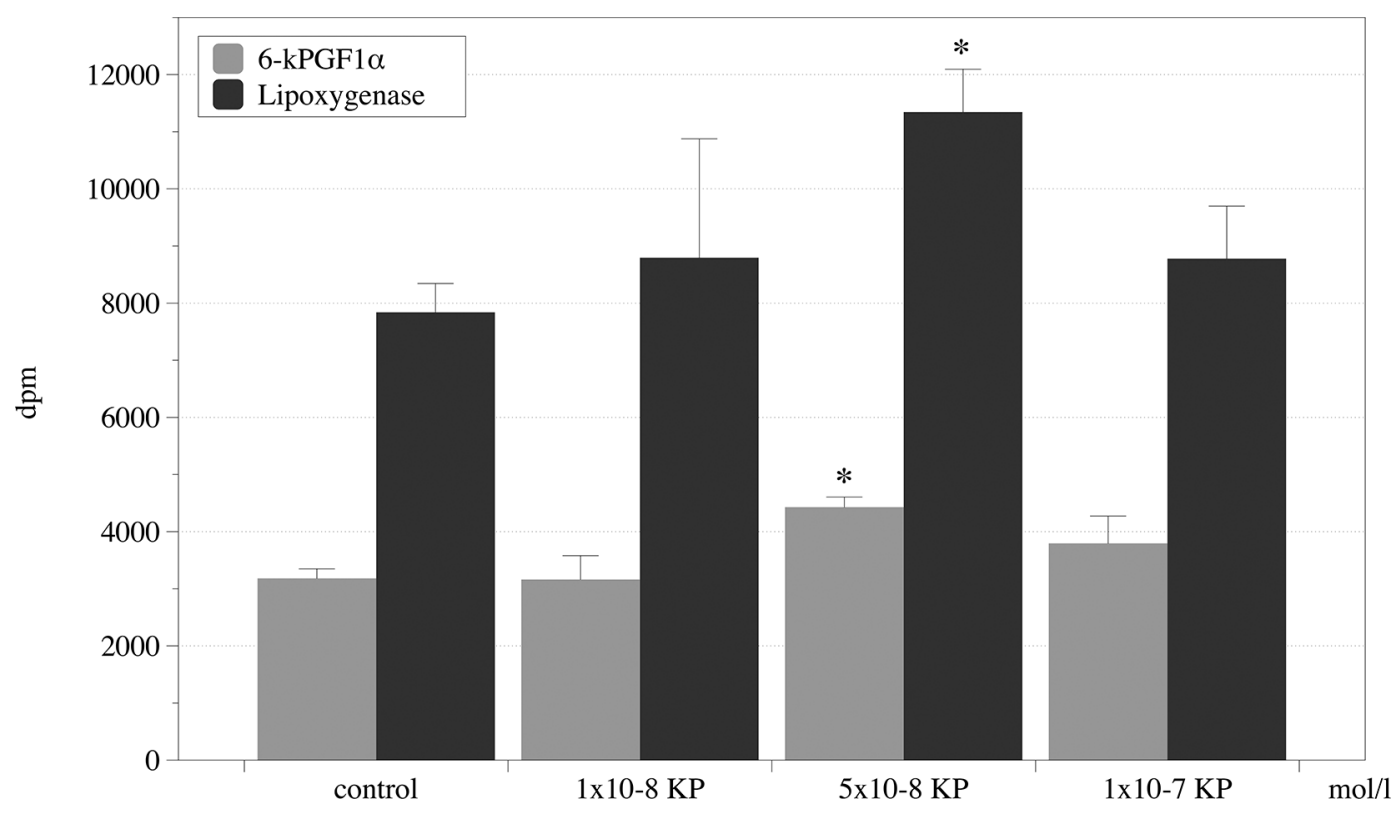

tion in response to KP that did not prove to be significant (not shown on the figure). On the other hand, $5 \times 10^{-8} \mathrm{~mol} / \mathrm{L}$ dose of KP-13 elicited a marked increase in the amount of LOX metabolites.

\section{Discussion}

In the present experiments, KP-13 stimulated both the COX and LOX pathways in platelets; however, the dose-response curves showed different characteristics. A KP dose of $2.5 \times 10^{-8} \mathrm{~mol} / \mathrm{L}$ caused a significant elevation in the amount of COX metabolites. However, further increasing the dose failed to increase COX production, rather a bell-shaped response was observed. Only a higher dose of KP was able to significantly stimulate the amount of LOX metabolites, and the dose-response curve showed a plateau when using higher doses. Furthermore, in platelet suspension, KP significantly increased the synthesis of $\mathrm{TxB}_{2}$. $\mathrm{TxB}_{2}$ is the stable metabolite of $\mathrm{TxA}_{2}$, which is the main vasoconstrictor and platelet activator COX metabolite of platelets (Kurahashi et al. 2003; Norel 2007; Félétou et al. 2010). KP causes an elevation of intracellular $\mathrm{Ca}^{2+}$ concentration, which generally stimulates phospholipase $\mathrm{A}_{2}$ and consequently leads to the activation of the whole arachidonate cascade, both the COX and the LOX pathways (Bonventre 1992; Chawengsub et al. 2009). Therefore, KP might exert its effects on the arachidonate metabolites through enhanced $\mathrm{Ca}^{2+}$ signaling (Castaño et al. 2009). However, the different pattern of COX and LOX pathway activation indicates that beyond increasing intracellular $\mathrm{Ca}^{2+}$ concentration, other signaling pathways, such as the ERK1/2 and the p38 MAP kinase, may also play a role (Castaño et al. 2009). In fact, literature suggests a link between the p38 MAP kinase pathway and LOX activation (Reddy et al. 2002).

Our results demonstrate that KP activates the arachidonate cascade not only in platelets but also in aorta slices. However, the pattern of metabolite production in aorta slices was different from that in platelets. KP produced a marked increase in the amount of the 6-kPGF ${ }_{1 \alpha}$, the stable metabolite of prostacyclin that exerts vasodilator and platelet inhibitory effect, and only a moderate increase in the total COX metabolites. This may suggest that the increased $6-\mathrm{kPGF}_{1 \alpha}$ takes up the majority of the changes displayed in the total COX metabolites. On the other hand, KP induced a significant elevation in the concentration of LOX metabolites in the aorta. It is also worth mentioning that the dose-response curve in the aorta for all metabolites was bellshaped and the same dose of KP evoked maximal changes in COX and LOX metabolites. Clearly, the different pattern of metabolite release in platelets and vessels can cause different end-effects as well. Metabolites released from platelets would probably result in vasoconstriction mediated mainly by $\mathrm{TxA}_{2}$ release. On the other hand, KP induces the synthesis of LOX products and $\mathrm{PGI}_{2}$, which might mediate relaxation of the vasculature. Our results seem contradictory; however, taken together with the conflicted data on this matter in the literature, it is possible that KP's action might be cell or tissue type-dependent and site-dependent (Kurahashi et al. 2003; Mead et al. 2007; Maguire et al. 2011; Sawyer et al. 2011). Therefore, the different receptor expression patterns, different signaling pathways, and the availability of different enzymes could well justify our results. Also, KP can act through multiple intracellular signaling pathways (Castaño et al. 2009) that may contribute to its effect. On the basis of our results, KP through the modification of eicosanoid synthesis may be involved in physiologic regulation of vascular tone and might influence pathologic conditions such as the inflammatory reaction and the course of hemostatic processes. It must be noted, however, that in our experiments, we investigated KP's effect on platelets and aorta isolated from healthy animals. Moreover, eicosanoid synthesis was assessed under resting conditions. All care was taken to prevent platelet activation during the experiment: no vasoconstrictors or platelet activators were applied. Also, the amount of the labeled arachidonic acid was only a fraction $(\mathrm{pmol} / \mathrm{mL})$ of what is required for aggregation $(\mu \mathrm{mol} / \mathrm{mL})$, and plastic tubes and instruments as well as EDTA were used throughout separation. The effects of KP could be mediated by a change in octadecanoid and docosanoid metabolism as well. However, the experimental setup used in this study is not suitable for the detection of these metabolites. Still, docosanoid production should be limited, since commercial rat pellet contained mainly saturated and $n-6$ polyunsaturated fatty acids (Russo 2009).

$\mathrm{KP}$ exerts its effects through the activation of 2 receptors, GPR54 and NPFF receptors (Castaño et al. 2009; Elhabazi et al. 2013). As NPFF receptors have already been implicated in cardiovascular control (Allard et al. 1995), it is plausible that KP binding 


\section{Pagination not final (cite DOI) / Pagination provisoire (citer le DOI)}

to NPFF receptors takes part, together with the other members of the RF-amide family, in the regulation of vascular tone (Sellers and Stallone 2008) and hemostasis (Qureshi Kanwal 2011). It is also possible that GPR54 binding mediates the effect of KP. Multiple data available in the literature might support this contention: first, distribution data on the expression of the GPR54 receptor (Hadi and Suwaidi 2007), and second, sex differences in vascular wall sensitivity to vasoconstrictor agents (Sellers and Stallone 2008; Nijher et al. 2010).

In conclusion, KP stimulated the COX and LOX metabolite production in platelets, however, in a different pattern than might be explained by the diverse intracellular signaling pathways activated by KP. Furthermore, in the aorta, KP evoked a significant increase in 6- $\mathrm{KPGF}_{1 \alpha}$ level and in LOX metabolite production. KP's actions on the eicosanoid synthesis of platelets and aorta may provide another layer of physiologic and (or) pathologic regulation of vascular tone.

\section{Acknowledgements}

This work was supported by grants ETT355-08/2009, TÁMOP 4.2.2.-08/1-2008-0013, TÁMOP 4.2.1./B-9/KONYV-2010-005, and TÁMOP 4.2.2.2-A-11/1KONYV-2012-0052, and by grant KTIA_13_NAP-AIII/8 from the Hungarian Brain Research Program.

\section{References}

Abdel-Halim, M.S., Lundén, I., Cseh, G., and Anggård, E. 1980. Prostaglandin profiles in nervous tissue and blood vessels of the brain of various animals. Prostaglandins, 19(2): 249-258. doi:10.1016/0090-6980(80)90023-4. PMID:6892961.

Allard, M., Labrouche, S., Nosjean, A., and Laguzzi, R. 1995. Mechanisms underlying the cardiovascular responses to peripheral administration of NPFF in the rat. J. Pharmacol. Exp. Ther. 274(1): 577-583. PMID:7616447.

Bogatcheva, N.V., Sergeeva, M.G., Dudek, S.M., and Verin, A.D. 2005. Arachidonic acid cascade in endothelial pathobiology. Microvasc Res. 69(3): 107-127. doi: 10.1016/j.mvr.2005.01.007. PMID:15896353.

Bonventre, J.V. 1992. Phospholipase A2 and signal transduction. J. Am. Soc. Nephrol. 3(2): 128-150. PMID:1391715.

Castaño, J.P., Martínez-Fuentes, A.J., Gutiérrez-Pascual, E., Vaudry, H., Tena-Sempere, M., and Malagón, M.M. 2009. Intracellular signaling pathways activated by kisspeptins through GPR54: Do multiple signals underlie function diversity? Peptides, 30(1): 10-15. doi:10.1016/j.peptides.2008.07.025. PMID:18775460.

Chawengsub, Y., Gauthier, K.M., and Campbell, W.B. 2009. Role of arachidonic acid lipoxygenase metabolites in the regulation of vascular tone. Am. J. Physiol. Heart Circ. Physiol. 297: H495-H507. doi:10.1152/ajpheart.00349.2009. PMID:19525377.

Cryer, B. 2009. Management of patients with high gastrointestinal risk on antiplatelet therapy. Gastroenterol. Clin. North Am. 38(2): 289-303. doi:10.1016/ j.gtc.2009.03.005. PMID:19446259.

Elhabazi, K., Humbert, J.P., Bertin, I., Schmitt, M., Bihel, F., Bourguignon, J.J., et al. 2013. Endogenous mammalian RF-amide peptides, including PrRP, kisspeptin and 26RFa, modulate nociception and morphine analgesia via NPFF receptors. Neuropharmacology, 75: C164-C171. doi:10.1016/j.neuropharm. 2013.07.012. PMID:23911743.

Eritsland, J. 2000. Safety considerations of polyunsaturated fatty acids. Am. J. Clin. Nutr. 71(1 Suppl.): 197S-201S. PMID:10617971.

Félétou, M., Köhler, R., and Vanhoutte, P.M. 2010. Endothelium-derived vasoactive factors and hypertension: possible roles in pathogenesis and as treatment targets. Curr. Hypertens. Rep. 12(4): 267-275. doi:10.1007/s11906-010-0118-2. PMID:20532699.

Fukusumi, S., Fujii, R., and Hinuma, S. 2006. Recent advances in mammalian RFamide peptides: the discovery and functional analyses of PrRP, RFRPs and QRFP. Peptides, 27(5): 1073-1086. doi:10.1016/j.peptides.2005.06.031. PMID: 16500002 .
Gawaz, M., Langer, H., and May, A.E. 2005. Platelets in inflammation and atherogenesis. J. Clin. Invest. 115: 3378-3384. doi:10.1172/JCI27196. PMID:16322783.

Hadi, H.A., and Suwaidi, J.A. 2007. Endothelial dysfunction in diabetes mellitus. Vasc. Health Risk Manag. 3: 853-876. PMID:18200806.

Kiefer, H.C., Johnson, C.R., Arora, K.L., and Kantor, H.S. 1975. Colorimetric identification of prostaglandins in subnanomole amounts. Anal. Biochem. 68(1): 336-340. doi:10.1016/0003-2697(75)90714-9. PMID:1190449.

Kobayashi, T., and Levine, L. 1983. Arachidonic acid metabolism by erythrocytes. J. Biol. Chem. 258(15): 9116-9121. PMID:6409900.

Kotani, M., Detheux, M., Vandenbogaerde, A., Communi, D., Vanderwinden, J.M., Le Poul, E., et al. 2001. The metastasis suppressor gene KiSS-1 encodes kisspeptins, the natural ligands of the orphan G protein-coupled receptor GPR54. J. Biol. Chem. 276(37): 34631-34636. doi:10.1074/jbc.M104847200. PMID:11457843.

Kurahashi, K., Nishihashi, T., Trandafir, C.C., Wang, A.M., Murakami, S., and Ji, X. 2003. Diversity of endothelium-derived vasocontracting factors arachidonic acid metabolites. Acta Pharmacol. Sin. 24(11): 1065-1069. PMID: 14627486.

Lyubimov, Y., Engstrom, M., Wurster, S., Savola, J.M., Korpi, E.R., and Panula, P. 2010. Human kisspeptins activate neuropeptide FF2 receptor. Neuroscience, 170(1): 117-122. doi:10.1016/j.neuroscience.2010.06.058. PMID:20600636.

Maguire, J.J., Kirby, H.R., Mead, E.J., Kuc, R.E., d'Anglemont de Tassigny, X., Colledge, W.H., et al. 2011. Inotropic action of the puberty hormone kisspeptin in rat, mouse and human: cardiovascular distribution and characteristics of the kisspeptin receptor. PLoS One, 6(11): e27601. doi:10.1371/journal.pone. 0027601. PMID:22132116.

Mead, E.J., Maguire, J.J., Kuc, R.E., and Davenport, A.P. 2007. Kisspeptins are novel potent vasoconstrictors in humans, with a discrete localization of their receptor, $\mathrm{G}$ protein-coupled receptor 54, to atherosclerosis-prone vessels. Endocrinology, 148(1): 140-147. doi:10.1210/en.2006-0818. PMID:17023533.

Mezei, Z., Kis, B., Gecse, A., Tajti, J., Boda, B., Telegdy, G., et al. 2000. Platelet arachidonate cascade of migraneurs in the interictal phase. Platelets, 11(4): 222-225. doi:10.1080/09537100050057666. PMID:10938901.

Nijher, G.M., Chaudhri, O.B., Ramachandran, R., Murphy, K.G., Zac-Varghese, S.E., Fowler, A., et al. 2010. The effects of kisspeptin-54 on blood pressure in humans and plasma kisspeptin concentrations in hypertensive diseases of pregnancy. Br. J. Clin. Pharmacol. 70(5): 674-681. doi:10.1111/j.1365-2125.2010. 03746.x. PMID:21039761.

Norel, X. 2007. Prostanoid receptors in the human vascular wall. ScientificWorldJournal, 7: 1359-1374. doi:10.1100/tsw.2007.184. PMID:17767355.

Price, D.A., and Greenberg, M.J. 1977. Structure of a molluscan cardioexcitatory neuropeptide. Science, 197(4304): 670-671. doi:10.1126/science.877582. PMID: 877582.

Qureshi, I.Z., and Kanwal, S. 2011. Novel role of puberty onset protein kisspeptin as an anticoagulation peptide. Blood Coagul. Fibrinolysis, 22(1): 40-49. doi: 10.1097/MBC.0b013e328340e6a7. PMID:21042204.

Raphael, W., and Sordillo, L.M. 2013. Dietary polyunsaturated fatty acids and inflammation: the role of phospholipid biosynthesis. Int. J. Mol. Sci. 14(10): 21167-21188. doi:10.3390/ijms141021167. PMID:24152446.

Reddy, M.A., Adler, S.G., Kim, Y.S., Lanting, L., Rossi, J., Kang, S.W., et al. 2002. Interaction of MAPK and 12-lipoxygenase pathways in growth and matrix protein expression in mesangial cells. Am. J. Physiol. Renal Physiol. 283(5): F985-F994. doi:10.1152/ajprenal.00181.2002. PMID:12372774.

Russo, G.L. 2009. Dietary $n-6$ and $n-3$ polyunsaturated fatty acids: from biochemistry to clinical implications in cardiovascular prevention. Biochem. Pharmacol. 77(6): 937-946. doi:10.1016/j.bcp.2008.10.020. PMID:19022225.

Sawyer, I., Smillie, S.J., Bodkin, J.V., Fernandes, E., O’Byrne, K.T., Brain, S.D., et al 2011. The vasoactive potential of kisspeptin-10 in the peripheral vasculature. PLoS One, 6(2): e14671. doi:10.1371/journal.pone.0014671. PMID:21347414.

Sellers, M.M., and Stallone, J.N. 2008. Sympathy for the devil: the role of thromboxane in the regulation of vascular tone and blood pressure. Am. J. Physiol. Heart Circ. Physiol. 294(5): H1978-H1986. doi:10.1152/ajpheart.01318.2007. PMID:18310512.

Taylor, J., Pampillo, M., Bhattacharya, M., and Babwah, A.V. 2014. Kisspeptin/ KISS1R signaling potentiates extravillous trophoblast adhesion to type-I collagen in a PKC- and ERK1/2-dependent manner. Mol. Reprod. Dev. 81(1): 4254. doi:10.1002/mrd.22279. PMID:24273038.

Tena-Sempere, M. 2013. Kisspeptins. In Handbook of biologically active peptides. Edited by J.A. Kastin. Academic Press, Boston, Mass., USA. pp. 819-827. 